\title{
Development of a GFP expression vector for Cucurbit chlorotic yellows virus
}

Ying Wei ${ }^{1}$, Xiaoyu Han ${ }^{1}$, Zhenyue Wang ${ }^{1}$, Qinsheng Gu${ }^{2}$, Honglian Li ${ }^{1}$, Linlin Chen ${ }^{1}$, Bingjian Sun ${ }^{1}$ and Yan Shi ${ }^{*}$

\begin{abstract}
Background: Cucurbit chlorotic yellows virus (CCYV), a bipartite crinivirus, causes chlorotic leaf spots and yellowing symptoms on cucurbit leaves. We previously developed an infectious clone of CCYV. Limited work has been conducted on the construction of a crinivirus green fluorescence protein (GFP) expression vector to date.

Finding: We constructed a CCY GFP expression vector using the "add a gene" strategy based on CCYV RNA2

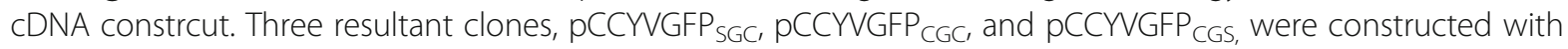
different promoters used to initiate GFP and CP expression. At 25 dpi GFP fluorescence was detectable not only in

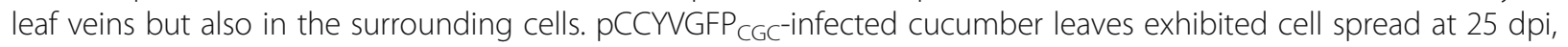
whereas pCCYVGFP SGC $_{\text {and }}$ PCCYVGFP CGS $_{\text {were mainly found in single cells. Further observation of PCCYVGFP }}$ CGC GFP expression at $30 \mathrm{dpi}, 40 \mathrm{dpi}$, and $50 \mathrm{dpi}$ showed phloem-limited localization in the systemic leaves.
\end{abstract}

Conclusions: We developed of a CCYV GFP expression vector that will be useful for further study of CCYV movement in cucurbits.

Keywords: CCYV, Controller elements, GFP expression

Cucurbit chlorotic yellows virus (CCYV), a recently discovered cucurbit-infecting crinivirus in the family Closteroviridae [1-7], is among the largest single-strand positive-sense RNA viruses [8]. The bipartite RNA genome comprises a 8607 nucleotide [nt] RNA1 and a 8041-nt RNA2. Recent studies on CCYV [9-12] have been hampered due to lack of reverse genetic tools. The construction of full-length infectious cDNA clones will facilitate the investigation of viral determinants of virus replication and movement, as well as the interactions between viral proteins and host factors. Our previous study developed two sets of full-length CCYV cDNA clones under the control of the T7 RNA polymerase promoter and $35 \mathrm{~S}$ promoter [13].

Virus-based vectors are useful tools for the study of plant molecular biology. A number of plant virus vectors have been developed to express heterologous genes of interest in plants [14-18]. Only LIYV has been reported to construct a green fluorescence protein (GFP) vector for crinivirus using the ORF fusion strategy. Part of

\footnotetext{
* Correspondence: shiyan00925@126.com

${ }^{1}$ College of Plant Protection, Henan Agricultural University, Zhengzhou 450002, China

Full list of author information is available at the end of the article
}

LIYV RNA1 encoded P34 protein was replaced by a GFP gene and further observation of Nicotiana benthamiana $\mathrm{Nb})$ leaves agro-infiltrated by the resultant clone displayed occasional single cells green fluorescence. Limited GFP expression has been observed in Nicotiana benthamiana plants, but in no other hosts. Cucumber is an economically important cultivated plant, and the available GFP expression vector of cucurbit viruses is limited [19]. In this study, we constructed a CCYV GFP expression vector using the "add a gene" strategy with an extra subgenomic RNA and a foreign GFP protein, according to a previous study of the closterovirus Citrus tristeza virus [20], which suggested that this strategy would be more appropriate than ORF substitution or ORF fusion. We examined the systemic leaves of cucumber plants regarding the resulting GFP fluorescence.

We chose to insert gfp ORF before the $\mathrm{CP}$ gene, because the CP subgenomic controller elements (CEs) are more suitable than other CEs [20-23]. The full-length CCYV RNA2 clone was modified to accommodate the $g f p$ gene immediately upstream of the $\mathrm{CP}$ open reading frame via overlapping polymerase chain reaction (PCR). Sweet potato chlorotic stunt virus (SPCSV) CP CEs were used to direct the expression of the CCYV CP gene or GFP. The 

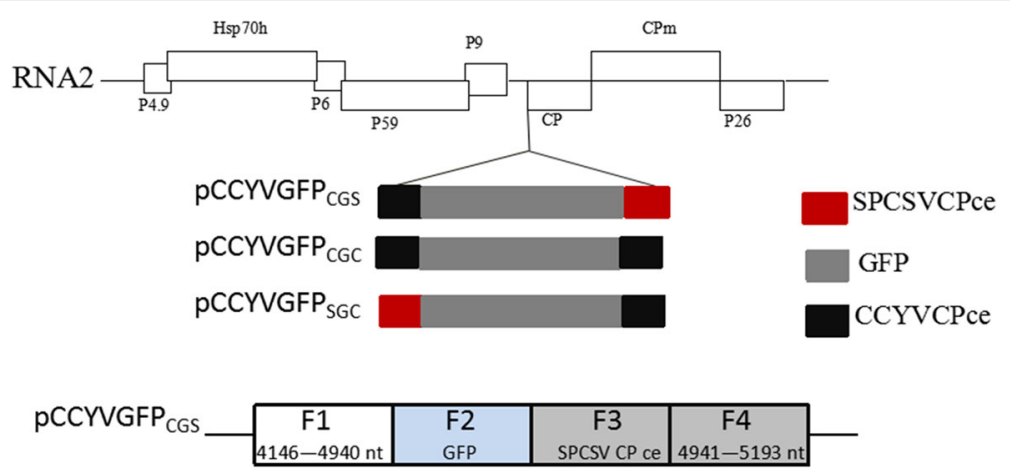

Fig. 1 Schematic representation of the construction of a green fluorescent protein (GFP) expression vector of Cucurbit chlorotic yellows virus (CCYV). GFP was inserted immediately upstream of the CP gene. Three different combinations of CCYV CP controller elements (CEs) and Sweet potato chlorotic stunt virus (SPCSV) CP CEs are shown. Red square indicates CEs of SPCSVCP; black square indicates CEs of CCYVCP. Grey square indicates the gfp gene

strategy used to construct the full-length cDNA clones of RNA1 and RNA2 is outlined in Fig. 1. The resulting clones were named pCCYVGFP $\mathrm{SGC}$, pCCYVGFP $_{\mathrm{CGC}}$, and pCCYVGFP $_{\text {CGs. To construct the clone pCCYVGFP }}$ CGS, four overlapping fragmens were amplified using the primer pairs showed in Table 1 and the recombinant fragment were obtained using overlap PCR. Restriction enzymes $M l u \mathrm{I}$ and $\mathrm{NruI}$ were used to insert the fragment into the pCBCCYVRNA2 to acquire the GFP-tagged vector pCCYVGFP CGS. Based on pCCYVGFP $_{\mathrm{CGS}}$, a fragment from 4811 to 5193 nt covering CCYVCP CEs and partial CP sequence was amplified using primer pair CCYVCcgccF2F/CCYVCcgscF2R. pCCYVGFP ${ }_{\mathrm{CGS}}$ and the fragment were digested by PacI and NruI to acquire the recombinant clone pCCYVGFP $_{\mathrm{CGC}}$. pCCYVGFP $_{\mathrm{SGC}}$ vector was cloned based on pCCYVGFP ${ }_{\mathrm{CGC}}$. Three overlapping fragments were amplified using primer pairs $\mathrm{CCYV}_{\text {cgsc }} \mathrm{F} 1 \mathrm{~F} / \mathrm{CCYVsgccF} 1 \mathrm{R}, \mathrm{CCYVsgccSPCSVCPpF/}$

Table 1 Primer sets used in the paper

\begin{tabular}{|c|c|}
\hline Primer name & Sequence $\left(5^{\prime}-3^{\prime}\right)$ \\
\hline CCYVcgscF1F & CTACTATTGGACGCGTTATTG \\
\hline CCYVcgscF1GFPR & CTCGCCCTTGCTCACCATATTAAATGTAGATCGAGT \\
\hline CCYVcgscGFPF & ACTCGATCTACATTAAATATGGTGAGCAAGGGCGAG \\
\hline CCYVcgscGFPR & ATACCAAGTITAATTAATCAAAGATCTACCATGTACAGC \\
\hline CCYVcgscSPCSVCPpF & AGATCTITGATTAATTAAAACTTGGTATCGCGGTTG \\
\hline CCYVcgscSPCSVpCPR & ATTGTCAGTCTTCTCCATACTCGTCTCACTGCTTAG \\
\hline CCYVcgscF2F & CTAAGCAGTGAGACGAGTATGGAGAAGACTGACAAT \\
\hline CCYVcgscF2R & CGAAATCCCTCATACACTGTTC \\
\hline CCYVCcgccF2F & CGCTTAATTAATCAGTGATTATCTTCAAATTC \\
\hline CCYVsgccF1R & ACCAACCGCGATACCAAGTTCAGTTAAAAAATITGGTA \\
\hline CCYVsgccSPCSVCPpF & TACCAAAATIITIAACTGAAACTTGGTATCGCGGTTGGT \\
\hline CCYVsgccSPCSVCPpR & CCTCGCCCTTGCTCACCATACTCGTCTCACTGCTTAGTT \\
\hline CCYVsgccGFPF & AACTAAGCAGTGAGACGAGTATGGTGAGCAAGGGCGAGG \\
\hline
\end{tabular}

CCYVsgccSPCSVCPpR, and CCYVsgccGFPF/CCYVcgsc F2R, and overlap PCR was used to ligate the fragments and inserted into $\mathrm{PCBCCYVRNA2} \mathrm{vector} \mathrm{using} \mathrm{restriction}$ enzymes $M l u \mathrm{I}$ and $\mathrm{NruI}$. The resultant clones were transformed into Agrobacterium tumefaciens strain GV3101 for agroinfiltration. At 25 days after agroinfiltration of pCCYVGFP with pCBCCYVRNA1 and pCBP1/HC-Pro in C. sativus, the adaxial side of leaf was used to observe the GFP fluorescence using epifluorescence microscope (Nikon ECLIPSE Ti-S) with the excitation of 460-480 nm and emission wavelength of $500-540 \mathrm{~nm}$, respectively (Fig. 2a). GFP fluorescence was detectable not only in leaf veins, but also in the surrounding cells. This result is consistent with that of a previous study of CCYV localization in leaf laminae using immunoblots [9]. We observed that

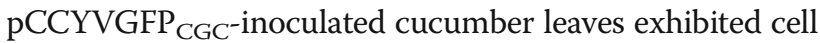
spread at $25 \mathrm{dpi}$, whereas the other two constructs were mainly found in single cells (Fig. 2b). The number of pCCYVGFP $_{\text {CGC }}$ fluorescent cells was significantly higher

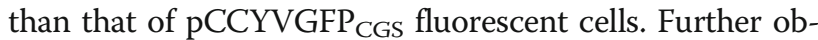
servation of pCCYVGFP ${ }_{\text {CGC }}$ at $30 \mathrm{dpi}$ showed that GFP was mainly vein-limited in cucumber systemic leaves

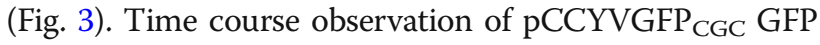
fluorescence showed that at $40 \mathrm{dpi}$ the GFP fluorescence was mainly focused in the second systemic leaf and at 50 dpi the fluorescence was mainly focused in the main vein of systemic leafs showing the most fluorescence in the third systemic leaf (Fig. 3).

As previously reported for the closterovirus CTV, a heterologous BYV sgRNA CE to control GFP expression was stable and worked best of the stratefies examined [20]. The closterovirus beet yellow stunt virus (BYSV) $248 \mathrm{bp}$ upstream of the $\mathrm{CP}$ coding region was chosen to direct the expression of BYV CP, and the original $\mathrm{CP}$ promoter was used to direct GFP expression [24]. We chose a 201-bp CE sequence upstream of the SPCSV CP coding region to test the heterologous effect, and a 


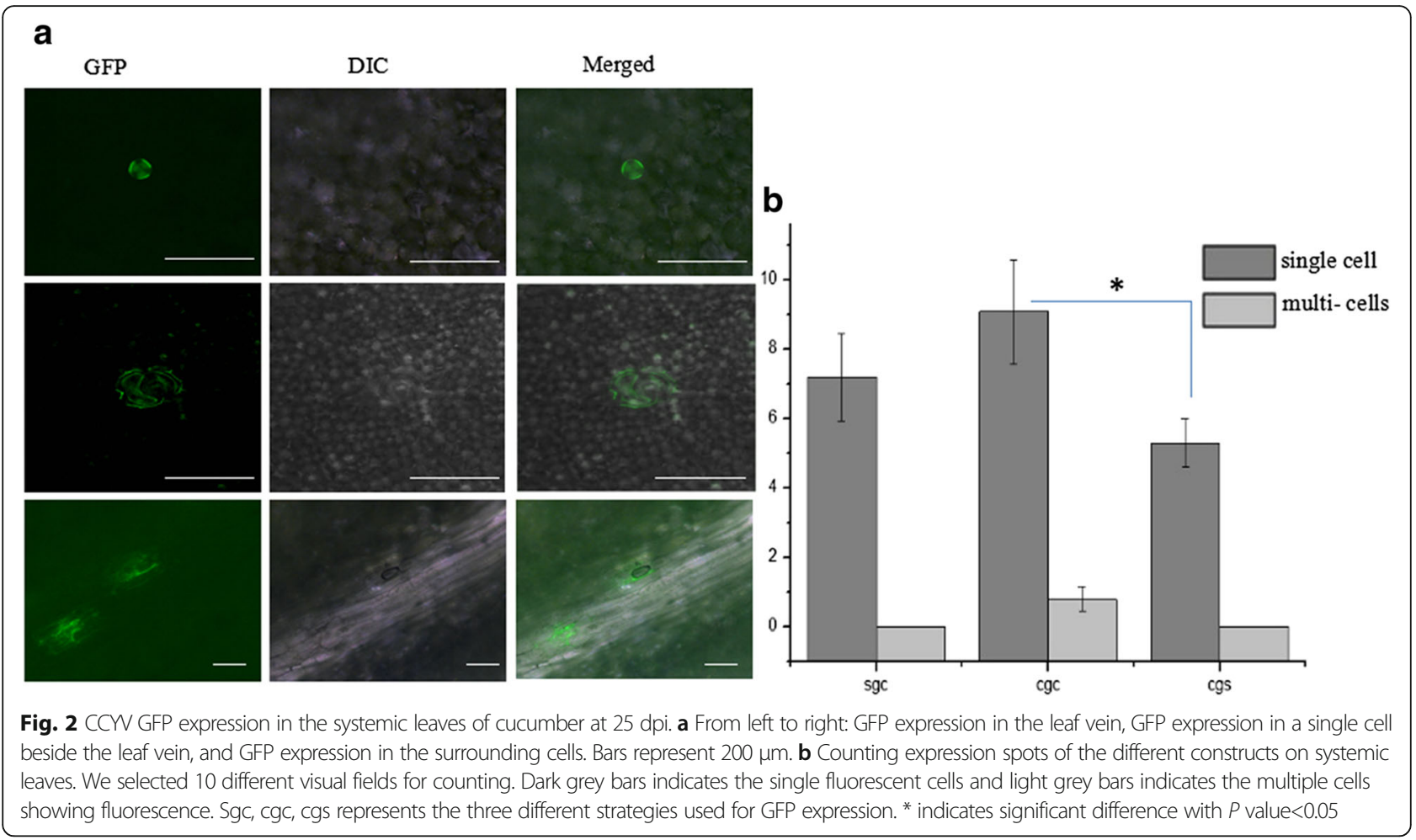

131-bp CE of CCYV CP to test the homologous effect. According to our results, the homologous sequence repeats in the vector promoted the GFP expression of CCYV, whereas when we used the CE of SPCSV CP to direct expression of CCYV CP or GFP, GFP expression was delayed. Hence, pCCYVGFP ${ }_{\mathrm{CGC}}$ can be used as a candidate for further study of GFP expression. Here we tested the insertion of GFP before the CP coding region. Other positions could be tested further to see if the other position would work better.

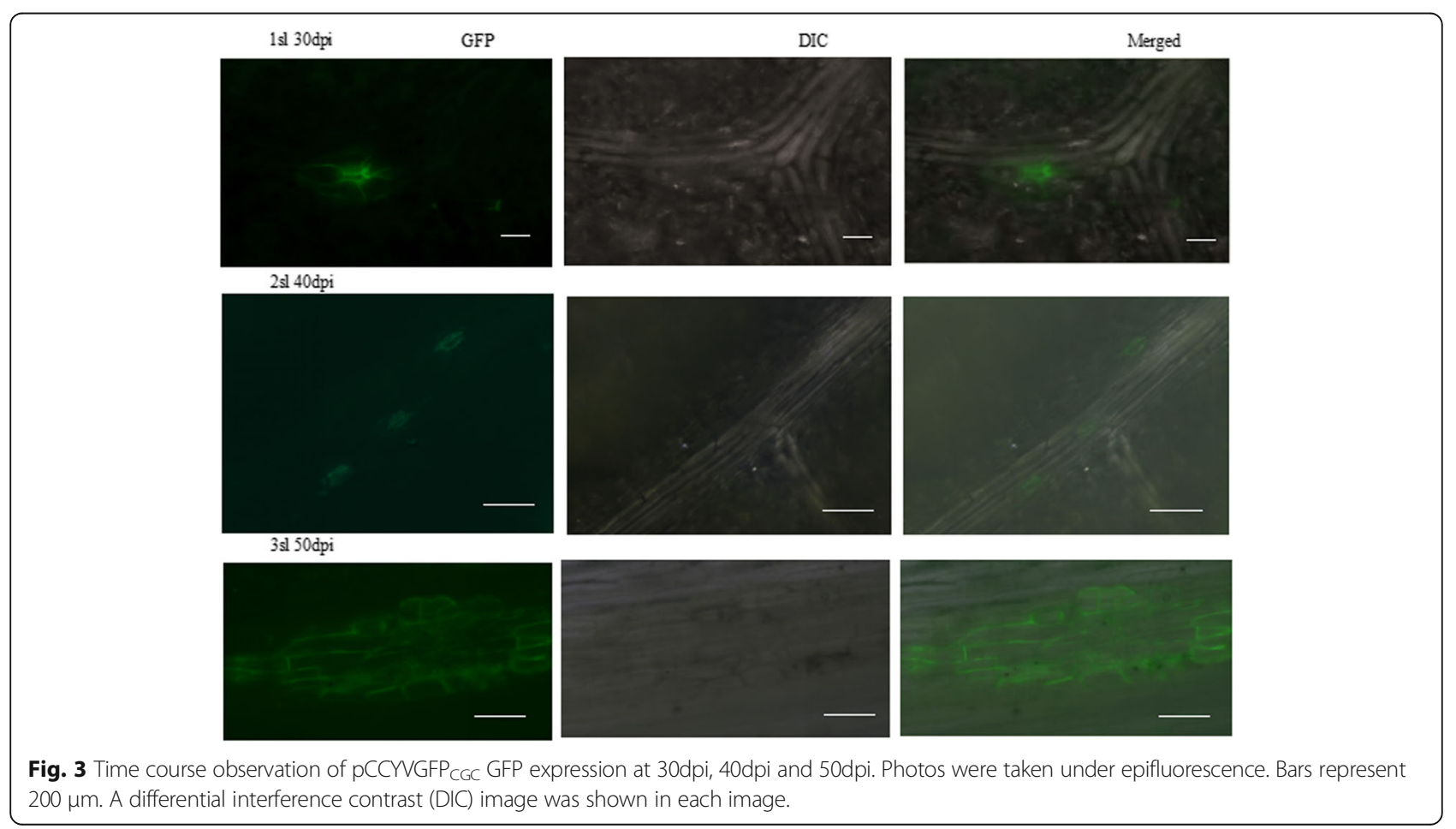




\section{Abbreviations}

CCYV: Cucurbit chlorotic yellows virus; CEs: controller elements; GFP: green fluorescent protein; SPCSV: Sweet potato chlorotic stunt virus

\section{Acknowledgements}

We thank Dr. Fengmin Yan for helpful comments on the preparation of this manuscript.

\section{Funding}

Financial support was provided by National Natural Science Foundation of China (31701944).

\section{Authors' contributions}

YS and ZW designed the experiment. YW performed the experiment and data analysis. YS and ZW wrote paper. QG, LC, HL, BS, XH were involved in discussion. All authors read and approved the final manuscript.

\section{Ethics approval and consent to participate}

Not applicable.

\section{Consent for publication}

All the authors consent to publish

\section{Competing interests}

The authors declare that they have no competing interests.

\section{Publisher's Note}

Springer Nature remains neutral with regard to jurisdictional claims in published maps and institutional affiliations.

\section{Author details}

${ }^{1}$ College of Plant Protection, Henan Agricultural University, Zhengzhou 450002, China. ${ }^{2}$ Zhengzhou Fruit Research Institute, Chinese Academy of Agriculture Sciences, Zhengzhou 450009, China.

Received: 4 January 2018 Accepted: 15 May 2018

Published online: 24 May 2018

\section{References}

1. Abrahamian P, Sobh H, Abou-Jawdah YA. First report of Cucurbit chlorotic yellows virus on cucumber in Lebanon. Plant Dis. 2012;96:1704.

2. Gu QS, Liu YH, Wang YH, Huangfu WG, Gu HF, Xu L, Song FM, Brown JK. First report of Cucurbit chlorotic yellows virus in cucumber, melon, and watermelon in China. Plant Dis. 2011:95:1168.

3. Huang LH, Tseng HH, Li JT, Chen TC. First report of Cucurbit chlorotic yellows virus infecting cucurbits in Taiwan. Plant Dis. 2010:94:1168.

4. Keshawarz T, Shams-Bakhsh M, Izadpanah K, Malboobi MA. Occurrence and genome analysis of Cucurbit chlorotic yellows virus in Iran. J Phytopathol. 2014;162:523-6

5. Okuda M, Okazaki S, Yanasaki S, Okuda S, Sugiyama M. Host range and complete genome sequence of Cucurbit chlorotic yellows virus, a new member of the genus crinivirus. Phytopathology. 2010;100:560-6.

6. Orfanidou C, Maliogka VI, Katis NI. First report of Cucurbit chlorotic yellows virus in cucumber, melon, and watermelon in Greece. Plant Dis. 2014;98: $1446-7$.

7. Hamed K, Menzel W, Dafalla G, Gadelseed AMA, Winter S. First report of Cucurbit chlorotic yellows virus infecting muskmelon and cucumber in Sudan. Plant Dis. 2011;95:1321.1.

8. Martelli IM, Agranovsky AA, Bar-Joseph M, Boscia D, Candresse T, Coutts RHA et al. Closteroviridae. In: Andrew MQ, King MJA, Carstens EB, Lefkowitz EJ, editors. Virus taxonomy classification and nomenclature of viruses ninth report of the international committee taxonomy of viruses. USA: Elsevier Inc.; 2012. p. 987-1001.

9. Kubota K, Usugi T, Tsuda S. Production of antiserum and immunodetection of Cucurbit chlorotic yellows virus, a novel whitefly-transmitted crinivirus. J Gen Plant Pathol. 2011:77:116-20.

10. Okuda S, Okuda M, Sugiyama M, Sakata Y, Takeshita M, Iwai H. Resistance in melon to Cucurbit chlorotic yellows virus, a whitefly-transmitted crinivirus. Eur J Plant Pathol. 2013;135:313-21.
11. Wang Z, Gu Q, Sun H, Li H, Sun B, Liang X, et al. One-step reverse transcription loop mediated isothermal amplification assay for sensitive and rapid detection of Cucurbit chlorotic yellows virus. J Virol Methods. 2014; 195:63-6.

12. Wang ZY, Wang YZ, Sun H, Gu QS, Li HL, Sun BJ, et al. Two proteins of Cucurbit chlorotic yellows virus, P59 and P9, are self-interacting. Virus Genes. 2015;51:152-5.

13. Shi Y, Chen L, Sun B, Sun X, Wang Z, Gu Q, et al. Infectious clones of the crinivirus Cucurbit chlorotic yellows virus are competent for plant systemic infection and vector transmission. J Gen Virol. 2016;97(6):1458-61.

14. Baulcombe DC, Chapman S, Santa Cruz S. Jellyfish green fluorescent protein as a reporter for virus infections. Plant J. 1995;7(6):1045-53.

15. Toth RL, Chapman S, Carr F, Santa Cruz S. A novel strategy for the expression of foreign genes from plant virus vectors. FEBS Lett. 2001;489(2-3):215-9.

16. Liu Z, Kearney CM. A tobamovirus expression vector for agroinfection of legumes and Nicotiana. J Biotechnol. 2010;147(3-4):151-9.

17. Shivprasad S, Pogue GP, Lewandowski DJ, Hidalgo J, Donson J, Grill LK, et al. Heterologous sequences greatly affect foreign gene expression in tobacco mosaic virus-based vectors. Virology. 1999;255(2):312-23.

18. Canizares MC, Lomonossoff GP, Nicholson L. Development of cowpea mosaic virus-based vectors for the production of vaccines in plants. Expert Rev Vaccines. 2005:4(5):687-97.

19. Rhee S-J, Jang YJ, Lee GP. Identification of the subgenomic promoter of the coat protein gene of cucumber fruit mottle mosaic virus and development of a heterologous expression vector. Arch Virol. 2016;161(6):1527-38.

20. Folimonov AS, Folimonova SY, Bar-Joseph M, Dawson WO. A stable RNA virus-based vector for citrus trees. Virology. 2007;368(1):205-16.

21. Ayllon MA, Gowda S, Satyanarayana T, Dawson WO. cis-acting elements at opposite ends of the Citrus tristeza virus genome differ in initiation and termination of subgenomic RNAs. Virology. 2004;322(1):41-50.

22. Gowda S, Satyanarayana T, Davis CL, Navas-Castillo J, Albiach-Marti MR, Mawassi M, et al. The p20 gene product of Citrus tristeza virus accumulates in the amorphous inclusion bodies. Virology. 2000;274(2):246-54.

23. Kurth EG, Peremyslov W, Prokhnevsky Al, Kasschau KD, Miller M, Carrington $\mathrm{JC}$, et al. Virus-derived gene expression and RNA interference vector for grapevine. J Virol. 2012;86(11):6002-9.

24. Peremyslov W, Hagiwara Y, Dolja W. HSP70 homolog functions in cell-tocell movement of a plant virus. Proc Natl Acad Sci U S A. 1999;96(26): 14771-6.

Ready to submit your research? Choose BMC and benefit from

- fast, convenient online submission

- thorough peer review by experienced researchers in your field

- rapid publication on acceptance

- support for research data, including large and complex data types

- gold Open Access which fosters wider collaboration and increased citations

- maximum visibility for your research: over $100 \mathrm{M}$ website views per year

At BMC, research is always in progress.

Learn more biomedcentral.com/submissions 